\title{
Avrupa Komisyonu Belgelerinde Sosyal Güvenliğin
}

\section{Yeniden Tanımlanması}

\section{Redefinition of Social Security in European Commission Documents}

\section{Varol DUR*}

\section{ÖZET}

Avrupa Birliği sosyal güvenlik ve sosyal koruma alanlarında üyelerini doğrudan bağlayıcı düzenlemeler yapmaktan imtina etse de bu alanlarda genel prensipler ortaya koyan belgeler yayınlamaktadır. Bu belgelerin temel hedefi sosyal güvenliği de içeren sosyal koruma sistemlerinin modernleştirilmesi olarak tanımlanmaktadır. Birlik tarafından ortaya konan kurallar, ilkesel düzeyde kalsa da, iş gücü piyasalarının dönüşümünün sosyal güvenlik üzerindeki yansıması olarak ortaya çıkmaktadır. AB'de Sosyal güvenliğin modernleştirilmesi olgusunu, esnek güvence yaklaşımı çerçevesinde incelemek doğru olacaktır. Bu çerçevede, makalenin amacı AB'de esnek güvence ve sosyal koruma sistemlerindeki dönüşüm arasındaki paralel gelişimi değerlendirmektir.

Anahtar kelimeler: Esnek güvence, sosyal koruma

\section{ABSTRACT}

Although European Union abstains from enacting directly binding regulations in the areas of social protection and social security, it published some documents puting general principles in these fields. Main essence of these documents is identified as modernization of social protection systems which include social security. Even if the rules established by EU are not behind the principles, they should be accepted as a reflection of transformation in the labour market on social security. Flexicurity is appropriate concept for analyzing modernization of social security issue in EU. In this scope, aim of this article is to evaluate parallel developments between flexicurity and transformation of social protection systems in EU.

Keywords: Flexicurity, social protection

\footnotetext{
* Sosyal Güvenlik Uzmanı, Sosyal Güvenlik Kurumu, Avrupa Birliği ve Yurtdışı İlişkiler Daire Başkanlığı, Ziyabey Cad. No:6 Ankara. e-posta: vdur@sgk.gov.tr, Tel: 03122078529
} 


\section{Giriş}

AB içerisinde ortak pazarın tedrici olarak derinleşmesi, Avrupalılar için rekabet baskısını artırırken, yapısal değişikliklerin hızlanmasında da tetikleyici rol oynamıştır. Yaşanan güncel krizler dünya içinde AB'nin rekabet gücünü daha da düşürken, son yirmi yıl içerisinde başta Avrupa olmak üzere gelişmiş ülkelerde vatandaşların yaşam ve çalışma biçimleri ciddi biçimde değişmiştir. Dört temel faktörün yaşanan değişikliklerden Avrupa'yı yoğun biçimde etkilemesine sebep olduğunu söylemek mümkündür; uluslararası ekonomik bütünleşme sürecinin hızlanması, özellikle bilgi ve iletişim teknolojilerdeki hızlı gelişim, yüksek işsizlik ve düşük istihdam oranı nedeniyle sürdürülebilir sosyal güvenlik sistemini de riske atan Avrupa toplumundaki hızlı yaşlanma sorunu ve işgücü piyasasının parçalanması sorunu. Bunlara yaşanan borç krizi ve bunun üye ülkelere eşitsiz etkisi de eklenirse, AB'de yaşanan tartışmaların derinleşmesi söz konusu olacaktır.

AB'nin karşılaş̧ı̆̆ı en önemli sorunun yaşanan bu değişimlere uyum sağlayamaması olduğu ileri sürülmekte olup, uyum yeteneğindeki yetersizliğinin en önemli sorumlusu olarak da esnek olmayan, korumac1 işgücü piyasaları gösterilmektedir. Ayrıca Maastricht Kriterlerinin uygulanmasını takip eden süreçte ülkelerin ekonomi yönetimleri üzerindeki güçlerinin kısıtlanması da işgücü piyasalarının düzenliyi araçlar olarak rollerini artırmıştır.

AB'nin işgücü piyasasına ilişkin sorunlarının çözümü için, firmalara iş potansiyellerini artıracak ve istihdam yaratmalarına imkân verecek şeffaf ve esnek yasal çerçeveye dayanan bir iş çevresi yaratırken, Avrupa vatandaşlarının istihdam imkânlarına olan güvenlerinin, insan kaynağının güçlendirilmesi gerektiğine inanılmaktadır. Dahası gençler, kadınlar ve yaşlılar gibi dezavantajlı grupların işgücü piyasasına girişlerinin kolaylaştırılmasına da özel önem verilmesinin gerekliliğinin altı çizilmektedir. Ayrıca çocuk bakımına yönelik imkânların yetersizliği kadınların işgücüne dahil olması önünde ciddi bir engel teşkil etmektedir. Etnik azınlıklar ve göçmenlerin işgücü piyasasına girişlerine yönelik de özel önlemlerin alınması gerekli görülmektedir 
Tüm bu sorunların çözümünün anahtarının daha esnek işgücü piyasası ile tatminkâr düzeydeki güvenlik olgusunun birlikte uygulanması olduğu yönündeki görüş $\mathrm{AB}$ bürokrasisi içinde ağır basmaktadır. Esneklik ve güvenliğin bu yeni formu firmalar ve bireyler için gerek $A B$ düzeyinde gerekse üye ülkeler düzeyinde 1990'ların başında tartışmaya açılmıştır.

$\mathrm{Bu}$ çalışmada yukarıda yapılan giriş ışı̆̆ında, AB'de sosyal koruma sisteminin esnek işgücü piyasalarına uyum sağlayacak biçimde yeniden yapılandırılmasına ilişkin hazırlanan yasal metinler ve bu çalışmaların ulaştı̆̆ nokta olarak kabul edilebilecek esnek güvence olgusu incelecektir.

\section{Sosyal Koruma Sisteminin Modernleştirilmesine İlişkin Komisyon Bildirileri}

Aşağıda incelenen iki Komisyon Bildirisinin de ortak özelliği $\mathrm{AB}$ sosyal koruma sistemlerinin "istihdam dostu" biçimde yeniden yapılanmalarını talep etmesidir. Her iki bildiride de kişilerin çalışma hayatları içerisinde daha uzun kalmalarını ya da iş gücü piyasası dışındaki kişilerin bir an önce çalışma hayatına dönmelerinin sağlayacak önlemleri içermektedir. Ayrıca yine iki bildiride de sosyal koruma sistemlerinin yarattığı mali yüklere vurgu yapılmakta, sistemlerin sürdürülebilirliği ve maliyet azaltıcı önlemlerin üzerinde durulmaktadır.

\subsection{COM (2003) 842 Sayılı Komisyon Bildirisi²}

$\mathrm{Bu}$ bildiri çalışabilirliği, çalışma yoluyla gelir elde etmeyi ve herkes için üst düzey sosyal korumayı sağlarken bir taraftan da üye ülkelerin bütçelerine yük getirmelerinden kaçınmayı hedeflemektedir. Üye ülkelerin sosyal koruma sistemlerini modernize etmek yüksek sosyal yardımların çalışma önünde olumsuz teşvik oluşturmasını engellemek ve doğru koşulları oluşturarak çalışmanın daha çekici hale getirilmesini sağlam açısından önem kazanmaktadır. "Çalışma yoluyla gelir elde etmek/ Making work pay" ifadesi, vergi ve sosyal yardım sisteminde yapilacak reform çalışmalarıyla bir işe girmenin, bir işte çalışmaya devam etmenin, verimliliği artırmanın ve eğitim ve öğrenime yatırım yapmanın daha cazip hale getirilmesi anlamına gelmektedir.

2 http://eur-lex.europa.eu/LexUriServ/LexUriServ.do?uri=COM:2003:0842:FIN:EN:PDF 
Bildiri, aşağıda sıralanan beş farklı işgücü piyasası durumu arasındaki geçişin başarı ile sağlanmasında rol oynayacak bir sosyal yardım sistemi önermektedir;

- Sosyal Yardımdan Çalışma Hayatına: Bazı üye ülkelerde kişilerin çalışmak yerine işsizlik yardımı tarzı sosyal yardımlar işe geçinmeyi tercih etmeleri, bu ülkeleri hak etme kriterlerini yardım almak için gereken gün sayılarını artırmak ya da işsizlere önerilen işlerin kabulünü zorlamak ya da aktif istihdam tedbirlerini yaygınlaştırmak gibi önlemler alarak daha sıkı hale getirmek durumunda bırakmıştır. Fakat bu tip önlemlerin fakirliğe ya da sosyal dışlanmaya neden olmaması için ciddi biçimde izlenmesi gerekmektedir.

Üye ülkeler üç temel grupta toplanabilecek önlemler ile sosyal yardımların çalışmayı engelleyici özelliği ile mücadele edebilirler;

- İşsizlik yardımlarının miktarını, süresini sınırlandırmak, yardımlara erişim için iş aramayı ya da aktif istihdam programlarına katılımı zorunlu kılmak,

- Çalışma ile elde edilen gelir ile işsizlik yardımlarını bütünleştirmek ya da atipik çalışanlara kısmi işsizlik yardımı yapmak

- Hem çalışanlar, hem de işverenler için daha uygun vergi ve sosyal güvenlik düzenlemeleri yapılması

- Aile ve İş Hayatının Bütünleştirilmesi: Komisyonun bu başlıkta iki hedefi bulunmaktadır; çocuk büyütürken aileleri desteklemek ve kişilerin bir işi kabul ederken ya da işgücüne katılımlarını devam ettirirken, ailelerinden kaynaklanan sorumlulukları ihmal etmemelerini sağlayabilmek. Bu çerçevede üye ülkeler çocuk parası ya da aile yardımı adı altında kimi sosyal ödemeler yapmaktadır. Diğer taraftan analık, ebeveynlik ya da ebeveyn izni hallerinde de çeşitli formlar altında yardımlar yapılmakta ve çalışılmayan zamanlar nedeniyle emeklilik haklarında kayıplar olmaması için borçlanma hakları düzenlenmektedir. Bu konuda yaşanan en önemli sorun, özellikle kadınlar ve yalnız ebeveynin çocuğunu gün içerisinde bırakabileceği yeterli çocuk bakım merkezlerinin bulunmamasıdır. Bunu engeli aşmak için 2010 
yılına kadar 3 yaş üstü küçük çocuklarda \%90, 3 yaş altında \%33 okullaşma oranı hedefi konmuştur. Ayrıca yalnız yaşayan ebeveynlerin desteklenmesi için yeni sosyal yardım araçları da gündemdedir.

- Mesleki ve Coğrafi Hareketliliğin Artırılması: İşü̈cünün $\mathrm{AB}$ içinde ve yapısal değişiklikler doğrultusunda meslekler arasında hareketliliğinin/dolaşımının sağlanması ekonomik etkinlik açısından zorunlu görülmektedir. Fakat iş ya da ülke değiştirenlerin zorunlu ya da mesleki emeklilik sigortalarından kaynaklanan mevcut haklarını kaybetmemelerinin sağlanması, yani haklarından kişiler ile dolaşımının sağlanması çok önemlidir. 1408/71 sayılı Tüzük'ün yerine geçen 883/2004 sayılı Tüzük bu durumun sağlanması için gereken önlemler göz önünde bulundurularak tasarlanmıştır.

- İşgöremezlikten Çalışmaya Geçiş: AB üyesi bazı ülkelerde çeşitli nedenlerden ötürü işgöremez ya da malul hale gelenlere ödenen ödeneklerin miktarı çok yüksek düzeylerdedir. $\mathrm{Bu}$ nedenle bu alanda çeşitli reform çalışmaları yürütülmektedir. Örneğin Finlandiya'da işi nedeniyle hastalanma riski olanlara, bu risk gerçekleşmeden rehabilitasyon hizmeti sağlanmaktadır. Hollanda ve Lüksemburg'ta işi nedeniyle işgöremez hale gelen personele, çalıştığı firmanın uygun bir iş bulması zorunluluğu getirilmiştir. Ayrıca işgöremezlik ya da maluliyet aylığ 1 alan kişilere kontrol muayenelerinin zorunlu tutulması ve bu kişileri işe alan ve bunlarla çalışmayı sürdüren işverene çeşitli teşvikler sağlanması birçok ülkede uygulanan düzenlemelerdir.

- Çalışma Hayatının Uzatılması: Sosyal koruma alanında üzerinde ilke olarak $\mathrm{AB}$ düzeyinde anlaşılan en önemli husus gelecekteki emeklilere yeterli bir gelir sağlanabilmesi için sistemin sürdürülebilirliğinin sağlanmasıdır. $\mathrm{Bu}$ çerçevede kullanılan araçlardan biri de yaşlı çalışanların, daha az efor gerektiren işlere kaymalarına imkân verecek kısmi emeklilik sistemlerinin hayata geçirilmesi ve bu yolla 55 - 64 yaş arası kişilerde istihdam oranının artırılmasıdır. Böylelikle kişiler daha uzun süre işgücü piyasasına dahil olacaklar ve daha uzun süre prim ödeyeceklerdir. 


\subsection{COM(2005) 706 Sayılı Komisyon Bildirisi ${ }^{3}$}

Sosyal güvenlik gibi üye ülkelerin ulusal sistemlerine sik1 sıkıya bağlı konularda $\mathrm{AB}$ düzeyinde politikalar üretilmesi için kullanılan açık koordinasyon yöntemi Avrupa İstihdam Stratejisi ile birlikte hayata geçirilmiştir ${ }^{4}$. Bu yöntem yetki ikamesi, uyum, karşılıklı öğrenme, bütünleşik yaklaşım ve amaçlara göre yönetim temel ilkelerine dayanmaktadır ${ }^{5}$. 2005 tarih ve 706 sayılı Komisyon Bildirisi ile açık koordinasyon yönteminin sosyal koruma ve sosyal içerme konularında nasıl işleyeceğine ilişkin tavsiyeler ve bu alanda hedefler yayınlanmıştır. $\mathrm{Bu}$ çerçevede üç temel hedef belirlenmiştir. Bunlardan ilki ulaşılabilir, etkin ve finansal olarak sürdürülebilir sosyal koruma sistemleri ve sosyal içerme politikalarıyla sosyal kaynaşma ve fursat eşitliğinin desteklenmesidir. İkincisi Lizbon istihdam hedefleri ve sosyal taraflarca yayınlanan Sürdürülebilir Gelişim Stratejisi doğrultusunda daha yüksek ekonomik büyüme ve daha fazla işin sağlanmasıdır. Son hedefse, bu alandaki politikaların üretimi, uygulaması ve izlenmesine sosyal tarafların katılımını geliştirmek, şeffaflığı sağlamak ve iyi yönetim ilkesini hayata geçirmektir.

$\mathrm{Bu}$ ilkelerin üç alanda ve bunların alt başlıklarında hayata geçirilmesi öngörülmektedir;

- Yoksulluk ve sosyal dışlanmanın yok edilmesi için önemli bir etki yaratmak

- En dezavantajlı gruplar başta olmak üzere yoksulluk ve dışlanma ile mücadele için iş gücüne katılım oranının yükseltilmesi ve bunun için aktif istihdam tedbirlerinin kullanılması.

- Ayrımcilığın tüm çeşitleri ile mücadele edilmesi.

- Mümkün olan tüm bütçe imkânlarının, bu mücadele için seferber edilmesi.

- Yeterli ve sürdürülebilir bir emeklilik sisteminin sağlanması

- Herkes için yeterli bir emeklilik gelirinin garanti altına alınması ve kişilerin emeklilik sonrasında makul bir seviyede yaşam standartlarını sürdürebilmesi.

- Daha uzun çalışma hayatı ve aktif yaşlanmayı

\footnotetext{
3 http://eur-lex.europa.eu/LexUriServ/LexUriServ.do?uri=COM:2005:0706:FIN:EN:PDF

4 Bu konudaki Komisyon Bildirisi için lütfen bkz: http://europa.eu/scadplus/leg/en/cha/ c10120.htm

5 Açık koordinasyon yöntemi (Open Method of Coordination) ile ilgili detaylı bilgi için lütfen bkz.: ab.calisma.gov.tr/dnn/sdTree_TRtranslated/files/Open $\% 20$ method $\% 20$ of $\% 20$ coordination_tr.doc
} 
destekleyerek, primler ve faydalar arasındaki dengeyi koruyarak ve kamu ve özel emeklilik fonlarının sürekliliğini sağlayarak finansal açıdan sürdürülebilir emeklilik sistemlerinin garanti altına alınması.

- Emeklilik sistemlerine ilişkin her türlü bilginin erişilebilir k1lınmas1.

- Ulaşılabilir, kaliteli ve sürdürülebilir sağlık hizmetleri ve uzun dönemli bakım hizmetlerini garanti altına almak

- İhtiyacı olan herkesin gelir durumuna bakılmaksızın sağlik hizmetleri ve uzun dönemli bakım hizmetlerine erişiminin sağlanması.

- Bakım alanında kaynakların etkin kullanımının desteklenmesi.

\section{Esnek Güvenceye İlişkin Komisyon Bildirisi - COM (2007) 359}

Esnek güvence sözcügü ilk kez 1990'ların ortalarında Hollanda'da hazırlanan iki kanun olan "Hollanda Esneklik ve Güvenlik Kanunu" ile "Aracılar Yoluyla İşçi Temini Hakkında Kanun"da kullanılmıştır. Bu iki kanun, bir taraftan işgücü piyasasına esneklik kazandırabilmek için işten çıkarmaya yönelik düzenlemeleri basitleştirmiş ve geçici istihdam ofislerini kurulmuş, diğer taraftan da esnek çalışanların güvenceleri artırılmıştır ${ }^{6}$. Bu kanunların hayata geçmesi ile birlikte Hollanda esnek güvence sistemi doğmuştur. Buna göre atipik ya da esnek çalışma biçimleri teşvik edilirken, atipik çalışanlar ile normal çalışma ilişkisi içerisinde çalışanlar arasındaki bu dengesizliğin sosyal haklar bakımından giderilmesi amaçlanmıştır.

Takip eden yıllarda, Hollanda modeline bir alternatif olarak Danimarka İşgücü Piyasası Modeli geliştirilmiştir. Model, liberal iş güvencesi yasaları, işsizler için üst düzey sosyal güvenlik ve genişletilmiş aktif işgücü piyasası programlarının bir birleşimi olarak ortaya çıkmıştır. Birçok uluslararası raporda Danimarka bu alanda iyi bir örnek olarak gösterilirken, OECD farklı belgelerde Danimarka'yı bu alanda en iyi

6 Ton Wilthagen, Frank Tros, The Concept of "Flexicurity": A New Approach to Regulating Employment and Labour Markets, 2004, www.tilburguniversity.nl/flexicurity/ publications/papers/fxp2003_4.pdf. 
ülke uygulamasına sahip devlet olarak kabul etmiştir ${ }^{7}$. Danimarka Esnek Güvence Modeli, atipik çalışma biçimleri üzerine eğilmek yerine düşük iş güvencesi yoluyla esnek istihdam, yüksek işsizlik yardımları yoluyla işsizler için sosyal güvenlik ve yaygın aktif istihdam tedbirleri yoluyla işsizlerin yetenek ve hareketliliklerinin artırılmasına dayanmaktadır ${ }^{8}$.

Ortaya konan ihtiyaç ve çeşitli ülkelerde ortaya çıkan örnek uygulamalara rağmen $\mathrm{AB}$ sistemi içinde esneklik-güvenlik dengesine nasıl ulaşılacağını tarif eden herhangi bir somut enstrüman ya da kılavuz ilkeye ilişkin çalışmalar 2000'li yılların ortalarına kadar somutlaşmamıştır. Bununla birlikte, bu yetersizliğin giderilmesi hakkında önemli bir adım Mart 2006'da toplanan Avrupa Konseyi'nin bildirisi ile atılmıştır.

"Avrupa Konseyi, çalışanlar ve girişimcilerin yeni koşullara uyum sağlayabilirliliklerinin geliştirilmesi için Ulusal Reform Programlarında kapsaml politika stratejilerinin daha sistematik biçimde yer almasının üzerinde önemle durmaktadır. Bu kapsamda, Avrupa Konseyi, üye ülkelerden esnek güvence kavramina temel mücadele alanlarından biri olarak özel önem göstermesini istemektedir. Avrupa rekabet, istihdam ve sosyal güvenlik arasındaki karşılıklı pozitif bağımlılıktan faydalanmak zorundadır. Bu nedenle, üye ülkeler, ulusal işgücü piyasalarındaki özel durumlara uygun olarak, bütünleşik bir esnek güvence yaklaşımı içerisinde, özel kurumsal yapılart adapte ederek ve isgü̈cü piyasası segmantasyonunu dikkate alarak işgücü piyasasinda ve sosyal politikalar alanlarında reform çalışmaları yürütmeye davet edilmektedir. Bu çerçevede, Komisyon, üye ülkeler ve sosyal taraflarında katılımı ile esnek güvence kavramı için ortak prensipler geliştirecektir. Bu prensipler, daha açık ve uyumlu işgücü piyasaları ve daha verimli işyerlerine ulaşılması için faydalı referanslar olabilecektir"."

$7 \quad$ Hans Jensen, Jorn Neergaard Larsen,, "The Nordic Labour Markets and The Concept of Flexicurity", European Policy Centre Working Paper No. 20, 2005, s. 2-3, http://www.da.dk/ bilag/05-09-14\%20The $\% 20$ Nordic $\% 20$ labour\%20markets $\% 20$ and $\% 20$ the $\% 20$ concept $\% 20$ of $\% 20$ flexicurity $\% 20(2)$.pdf.

8 Maarten Keune, "Flexicurity: The New Cure for Europe's Labour Market Problems?", Social Develeoments in the European Union, Belçika, 2007, s.157.

9 http://www.consilium.europa.eu/ueDocs/cms_Data/docs/pressData/en/ec/89013.pdf 
$\mathrm{Bu}$ Konsey bildirgesinde bahsedilen en önemli hususun Komisyondan üye ülkeler ve sosyal tarafların da katılımı ile esnek güvence alanındaki ortak prensipleri belirlemesinin istenmesi olduğu göze çarpmaktadır. Bu amaç doğrultusunda 2007 yılı Haziran ayında Komisyon, 359 sayılı ve "Esnek güvence Alanında Ortak Prensiplere Doğru: Esneklik ve Güvenlik Yoluyla Daha Çok ve Daha İyi İstihdam” başlıklı bir bildiri (communication) yayınlamıştır.

Bildiride, Komisyon esneklik kavramını, okuldan iş hayatına, bir işten diğerine, işsizlikten çalışma hayatına ya da çalışma hayatından emekliliğe gibi hayatın çeşitli evreleri arasındaki geçişlerin sorunsuz yapılabilmesi, işe eleman alma ve işten çıkarmanın önündeki engellerin azaltılması şeklinde tanımlamaktadır. Bu tanım işçilerin daha iyi işlere doğru ilerleyişine ve yetenekleri doğrultusunda gelişimlerini sağlamaya yöneliktir. Aynı zamanda esneklik, gerektiğinde hızlı ve verimli biçimde üretim yapısının değiştirilebildiği esnek iş organizasyonlarının kurulması ile özel ve iş hayatlarına dair sorumlulukların kaynaştırılmasının kolaylaştırılması amaçlarını taşımaktadır. Yine bildiride, güvenlik ise sadece bir işçinin işten atılmasının yasal yollarla engellenmesinden ziyade kişilerin kariyerlerinde ilerlemelerini ve gerektiğinde yeni bir iş bulabilmelerini sağlayacak biçimde yeteneklerle donatılması ile ilgili bir olgu olarak tanımlanmaktadır. Aynı zamanda, kişilerin işsizlik dönemlerinde korunmaları da güvenlik kavramının bir gereği olarak sayılmıştır. Son olarak, güvenlik kavramı özellikle düşük nitelikti işçiler ile belli bir yaşın üzerindekiler için eğitim imkânlarının sağlanmasını da içermektedir.

Komisyon Bildirisinde, esnek güvenceye ilişkin politikaların dört bileşen altında belirleneceğini ifade etmektedir;

1. Modern iş kanunları, toplu sözleşme ve iş organizasyonları yoluyla esnek ve güvenilir sözleşmeye dayanan anlaşmalar (hem işçi, hem işverenin bakış açısından ve çalışanların olduğu kadar işsizlerin de işine yarayacak biçimde).

2. Özellikle en dezavantajlı gruplar için olmak üzere tüm çalışanların yeni durumlara uyum yeteneklerini ve istihdam edilebilirliklerini garanti altına alacak biçimde kapsamlı yaşam boyu öğrenme stratejisinin geliştirilmesi.

3. İnsanların hızlı değişimlerle başa çıkabilmelerine yardım etmek, işsizlikte geçen sürelerini kısaltmak ve yeni işlere geçişlerini kolaylaştırmak için aktif işgücü piyasası politikalarını geliştirmek. 
4. Kişilere uygun bir gelir sağlamak, istihdamı teşvik etmek ve işgücü piyasası hareketliliklerini desteklemek amacıyla sosyal güvenlik politikalarının modernleştirilmesi. Aynı zamanda, sosyal koruma araçları ile (emeklilik, sağlık, işsizlik güvenceleri) kişilerin işe ilişkin sorumlulukları ile çocuk bakımı gibi özel hayata ilişkin sorumluluklar arasındaki uyumun sağlanmas $1^{10}$.

Komisyon yayınladığı bu bildiri ile Avrupa iş gücü piyasasının sorunlarının ilacının esnek güvence olduğunu vurgularken, tam istihdama ulaşma hedefi ile ekonomik ve sosyal önceliklerin kombinasyonun sağlanmasında önemli bir araç olduğunun da altını çizmektedir. Komisyon esnek güvenceyi, literatürde genel kabul gören tanımlara uygun olarak; "Eş zamanlı ve bilinçli bir biçimde uygulanacak bir politik strateji ile bir taraftan işgücü piyasası, iş organizasyonu ve çalışmailişkilerinde esnekliği, diğer taraftansa istihdam güvencesi/istihdam edilebilirlik ile sosyal güvenlik/gelir güvencesinin kuvvetlendirilmesi” şeklinde tanımlamıştır ${ }^{11}$. Böyle bir stratejinin her şeyden önce firma ve bireylerin küresel ekonominin dalgalanmalarına karşı hem uyum yeteneklerini geliştireceği, hem de bu yeteneğe olan ihtiyaçlarını artıracağ işgücü piyasası esnekleşirken, hem işçilerin, hem de işverenlerin ihtiyaç duyacakları güvencelerin eş zamanlı olarak uygulamaya konulmasını gerektirmektedir. Büyüme ve İş için Birleştirilmiş Strateji (2008-2010) dokümanında bu durumun firmalar için anlamı, “...ihtiyaç duyduklarında çalışanlarını ekonomik koşullara göre değiştirebilmeleridir. Firmalar koşullara uygun niteliklere sahip daha üretken ve yenilikçilik ve rekabete daha uyumlu personeli işe alabilmelilerdir" şeklinde tanımlanmıştır. Bireyler ise artık iş güvencesinden ziyade istihdam güvencesine ihtiyaç duymaktadırlar. Stratejiye göre istihdam güvencesi, bireyin aktif çalışma hayatının her anında iş bulabilmesini ve değişen ekonomik ortama uygun biçimde gerektiğinde sıklıkla iş değiştirerek kariyerini geliştirme imkânını artırabilmesi anlamına gelmektedir. Bunun yanında stratejiye göre esnek güvence, işgücü piyasasının parçalanmasını azaltacağı gibi

10 Avrupa Komisyonu, Towards Common Principles of Flexicurity: More and Better Jobs Through Flexibility and Security, s. 37, http://ec.europa.eu/employment_social/employment_ strategy/flexicurity\%20media/flexicuritypublication_2007_en.pdf, (12.08.2008).

11 What is Flexicurity, http://ec.europa.eu/employment_social/employment_strategy/ flex_meaning_en.htm, (12.08.2008). 
işgücü piyasasına dahil olup iyi korunanlar ile dışarıda kalan işsizler arasındaki dengesizliği de azaltacaktır ${ }^{12}$.

Komisyon bildirisinde esnek güvenceye ilişkin genel prensipleri de ortaya koymuştur;

- Esnek güvence, esnek ve güvenilir bir kontrata dayanan işleri, geniş kapsamlı hayat boyu öğrenim metotlarını, etkin aktif istihdam tedbirlerini ve modern sosyal güvenlik sistemini ihtiva eder. Esnek güvencenin amacı Büyüme ve İş Stratejisinin uygulamasını güçlendirmek, daha iyi ve çok iş yaratılmasını sağlamak ve Avrupa Sosyal Modelini kuvvetlendirmektir.

- Esnek güvence işveren, işçi, iş arayanlar ve kamu otoritesi arasında haklar ve sorumluluklar anlamında denge gözetmektedir.

- Esnek güvence iş gücüne dahil olanlar ve olmayanlar arasındaki ayrımı azaltma amacını taşımaktadır. Mevcut çalışanlar işten işe geçiş konusunda hazırlıklı olma konusunda desteklenmeye ve bu durum esnasında korunmaya ihtiyaç duymaktadırlar. Mevcut iş arayanlar ise iş hayata giriş/dönüş için bir giriş noktasına ve düzenli işe geçiş için bir atlama taşına ihtiyaç duymaktadırlar.

-Esnek güvence üye ülkelerin ihtiyaçları doğrultusunda adapte edilebilir bir yapıdadır. Bir ülkeye ya da bir işgücü piyasasına göre tasarlanmamıştır.

- İçsel (firma içinde) ve dışsal (firmalar arasında) esneklik teşvik edilmelidir. İşe alma ve işten çıkarma konularındaki esneklik mutlaka yeterli istihdam güvencesi ile desteklenmelidir. Yüksek kaliteli işyerleri, iyi çalışma organizasyonları ve sürekli nitelik geliştirme imkânı esnek güvencenin amaçları arasındadır. Sosyal koruma hareketliliği destekler nitelikte olmalıdır.

- Esnek güvence erkek ve kadının işgücü piyasasına eşit biçimde girişini sağlama amacını taşımaktadır. Ayrıca iş ve özel hayat arasındaki dengenin sağlanması ile dezavantajlı grupların iş gücü piyasasına dahil olmalarının desteklenmesi de esnek güvencenin hedefleri arasındadır.

-Esnek güvence, sosyal taraflar ve kamu otoritesi arasında değişim için güvene ve diyaloga dayalı bir ortamı gerektirmektedir.

- Esnek güvence sağlam ve istikrarlı bir bütçe yapısına katkıda bulunacak biçimde uygulanmalıdır. Ayrıca ortaya çıkacak

12 Avrupa Komisyonu, Integrated Guidelines For Growth And Jobs (2008-2010), s.

30, http://ec.europa.eu/growthandjobs/pdf/european-dimension-200712-annual-progressreport/200712-annual-report-integrated-guidelines_en.pdf, (12.08.2008). 
maliyet, firmaların, kişilerin ve kamunun bütçelerine adil biçimde dağıtılmalıdır ${ }^{13}$.

Komisyon esnek güvece politikaları hakkında işbirliğine önem veren bir yaklaşım içerisindedir. Politikanın başarı ile uygulanması için sosyal tarafların aktif katılımı, iyi organize edilmiş ve işçi, işveren, devlet ve diğer tarafların katılımının sağlandığ 1 sosyal diyalog mekanizmaları hayati olarak görülmektedir. Fakat bu anlayış çeşitli soru işaretlerini de beraberinde getirmektedir. Hollanda, Danimarka ve Almanya gibi büyük ölçekli reformlar hazırlayan ülkelerde işbirliği yaklaşımı izlenmiştir. Fakat diğer taraftan tüm tarafları içeren bir uzlaşma arayışı, reform çabalarını engelleyebilecektir. Özellikle istihdamı teşvik etse de sosyal koruma sisteminde kısıtlamalara gidilmesini öngören çalışmaların zaman zaman toplumsal karşı çıkışa rağmen devam ettirildiğini görmek de mümkün olmaktadır ${ }^{14}$. Fakat Komisyon bildirisinin yayınlanmasının ardından Avrupa düzeyinde örgütlenmeye sahip sosyal paydaşlar genel olarak bu girişimi destekler nitelikte açıklamalar yapmışlardır. Avrupa Sendikaları Konfederasyonu (ETUC), bazı şüpheleri olmakla birlikte, Avrupa çapındaki bu girişimi olumlu karşıladıklarını açıklamıştır. Avrupa'nın en büyük işveren organizasyonu olan Euro Business'da (eski UNICE - Birleşmiş Milletler Avrupa Ekonomik Komisyonu) esnek güvence çağrısını desteklerken, küçük işletmelerde Avrupa düzeyinde işverenleri örgütleyen UEAPME, esnek güvencenin işgücü piyasasının modernleşmesi için tek yol olduğunu belirtmiştir ${ }^{15}$.

Avrupa Komisyonu'nun kendisi de üye ülkeler için tek bir esnek güvence modeli öneremeyeceğini kabul etmektedir. Her ülke etkin uygulamalar için kendi yolunu takip etmelidir. Fakat 2007 tarihli Komisyon Bildirisinde, ülkelerin izleyebilecekleri dört patika ${ }^{16}$ belirlenmiştir. Üye ülkeler kendi ihtiyaçlarına göre bir yol seçebileceği gibi, birden fazla patikayı birleştirebilmektedirler;

13 Avrupa Komisyonu, Towards Common, s. 9

14 Lars Calmfors, Flexicurity - An Answer or a Question, European Policy Analysis, İsveç, 2007, s.4, www.sieps.se/epa/2007/EPA_6_2007.pdf (12.04.2008).

15 Maarten Keune, Maria Jepsen, "Not Balanced and Hardly New: the European Commission Quest for Flexicurity”, ETUI- REHS, 2007,s.8,9, www.etui-rehs.org/research/content/download/2736/17963/version/2.

16 European Expert Group on Flexicurity, Flexicurity Pathways, 2007, s. 23-34, http://ec.europa.eu/employment_social/employment_strategy/pdf/flexi_pathways_en.pdf (14.04.2008) 
Patikalarda ilki, atipik çalışanlar ve standart çalışanlar arasındaki ayrımın derin olduğu ülkeler için işgücü piyasasının bölünmesi ile mücadele amacını taşıyan önlemler içermektedir. Bu önlemlerin başında atipik çalışma biçimlerine ilişkin iş akitlerine yönelik düzenlemelerin ülkelerin iş ve sosyal güvenlik mevzuatlarına, toplu pazarlık sistemlerine ve hayat boyu öğrenme stratejilerine entegre edilmesidir. Bunun yanında kişinin aynı işte kaldığ 1 süre artıkça, standart çalışma biçimleri için öngörülen güvenceye ulaşabilen prograsif koruma tedbirlerine izin veren, açik uçlu atipik iş akitlerinin sisteme dahil edilmesi de önerilmektedir. Esnek çalışanların istihdam edilebilirliğinin artırılması için eğitim imkânlarına erişimlerinin kuvvetlendirilmesi ve özellikle kadınlar için ev ve iş hayatlarını bütünleştirecek çalışma biçimlerinin yaygınlaştırılması bu patika kapsamında önerilen önlemlerdendir. Tüm bunlar yapılırken, esnek çalışanların sosyal güvenlik sistemine erişimlerinin sağlanması içinde gerekli tedbirlerin alınması gerekmektedir.

İkinci patika, güvenli ve başarılı iş değiştirmeyi garanti altına almayı hedeflemektedir. Kişinin işsiz kalma tehlikesi ile karşı karşıya kalması ya da kendisinin işini değiştirmek istemesi hallerinde işveren, sosyal taraflar ve kamu iş bulma kurumunun ortak girişimi ile kişiye iş değiştirme garantisi sağlanmalıdır. Hem meslek içi, hem de dışarıdan sağlanacak güçlü bir ömür boyu öğrenme ve mesleki eğitim sistemi ve bu eğitimlerin verilmesi için kullanılan fonlara kolay erişim, kişilerin iş değiştirmelerini kolaylaştırırken, iş gücü piyasasında da hareketliliği sağlayacaktır.

Üçüncü patika, işçiler arasında nitelikler açısından önemli farklılıklar olan ülkeler için önerilmekte olup, araştırma ve geliştirme faaliyetlerinin geliştirilerek ve aktif istihdam ve yaşam boyu öğrenme politikalarını sistematik biçimde kullanarak insan kaynağına yatırım yapılmasını önermektedir. Böylelikle yaşlılar, kadınlar, diplomasızlar gibi spesifik grupların istihdam edilebilirliği artacaktır. Ayrıca bu kişiler için bir başlangıç noktası olabilecek yarı zamanlı işler, belirli süreli iş akitleri gibi çalışma biçimleri yaygınlaştırılma ve kişilere özel hayatlarıyla iş hayatlarını bütünleştirme imkânı tanınmalıdır.

Sonuncu patika ise sosyal yardım alanlar ve kayıtdışı çalışanlar için istihdam imkânlarının artırılması amacını taşıyan önlemleri içermektedir. 
Aktif istihdam tedbirleri ve sosyal güvenlik önlemleri, kişilerin iş hayatlarını geri dönüşlerini sorunsuz hale getirecek, kolaylaştıracak ve teşvik edecek tedbirler içerecek biçimde kurgulanmalıdır. Sosyal güvenliğin sağladığı yardımların kişileri, çalışma hayatının dışında kalma yönünde kışkırtacak düzeyde olmaması gerekmektedir. Uzun dönemli yardımlara bağlılığın mutlaka önüne geçilmelidir. Kayıtlı istihdamın teşviki için atipik çalışma biçimleri ve daha düşük prim ve vergi oranları gibi önlemler öne çıkartılmalıdır. Kurumsal yapının güçlendirilmesi için sosyal tarafların karar verici konuma geçmeleri desteklenmeli, sektörel, bölgesel ve ulusal iki ya da üç taraflı sosyal diyalog güçlendirilmelidir.

Komisyonun esnek güvenceye ilişkin yayınladığ 1 tüm dokümanlarda geniş bir bakış açısı ile konuya yaklaştığını ve iddialı hedefler ortaya koyduğu görülmektedir. Avrupa çapında pek çok paydaşı ilgilendiren esnek güvence alanında birbirinden çok farklı işgücü piyasalarına sahip 27 üye ülkeye yönelik olarak hazırlanan bu dokümanlarda, böylesi bir yaklaşımla karşılaşmak şaşırtıcı değildir. Komisyon, esnek güvenceye ilişkin önerilerini ve ilkeleri sıralarken, işler ve üye ülkeler arasında dolaşımın yaygın olduğu, istihdam güvencesi yoluyla istihdam edilebilirliğin desteklendiği ve sosyal güvenliğin işsizlik döneminde işçiler için gelir güvencesi sağladığ 1 bir işgücü piyasasını varsaymaktadır. Fakat bunun pratikte nasıl uygulanacağı konusunda bazı sorular bulunmaktadır. Ayrıca esnek güvence modellerinin teorik alt yapısı ile pratik uygulamaları arasında da ciddi farklılıklar olabileceği ileri sürülmektedir.

Öncelikle, AB, ekonomik aktivitenin ve yüksek verimliliğin desteklenmesi için Avrupa işgücü piyasasının esnekliğinin artırılmasının öneminin altını çizmektedir. Bu amaçla, Avrupa Komisyonu içsel ve dışsal esneklik kapsamında iş güvencesi yerine istihdam güvencesini desteklemektedir. 2006 İstihdam Raporu'nda "Esnek güvence alanındaki $\mathrm{AB}$ bildirisinin temel atılımı, iş güvencesinden istihdam güvencesine geçişi teşvik etmektir"17 ifadesine yer verilmektedir. Görüldüğü üzere, AB sık1 istihdam koruma tedbirlerine taraftar olmadığ 1 gibi, mevcutları da esnek güvence yoluyla azaltma eğilimindedir. Bununla birlikte, dışsal esnekliğin işgücü piyasasına etkisine ve istihdam ile istihdam koruma tedbirleri arasındaki ilişkiye dair açık kanıtlar bulunmamaktadır. Ayrıca

17 Avrupa Komisyonu, Employment in Europe, 2006, s. 94, http://ec.europa.eu/ employment_social/employment_analysis/eie/eie2006_chap2_en.pdf. 
Komisyon bu tercihinin nedenini açıklamakta yetersiz kaldığı kimi görüşler tarafından savunulmaktadır. Komisyon bu konuda hızlı teknolojik gelişim ve artan rekabet ortamının esnek güvenceyi gerektirmesi gibi açık olmayan ve kanıtları tartı̧̧malı bir söylem içerisindedir. Komisyon bir taraftan 2006 İstihdam Raporu'nda İstihdam Koruma Tedbirleri ile işsizlik düzeyi arasında açık ilişki olmadığını ifade eden OECD raporlarına atıf yaparken, diğer taraftan dışsal esnekliğin artırılmasını destekleyen raporlar ve bildiriler yayınlamaya devam etmektedir ${ }^{18}$. Bu anlamda bir diğer soruda istihdam edilebilirliğin artırılması için düzenlenecek yaşam boyu eğitim ve aktif istihdam politikası faaliyetlerinin, işgücü piyasasının arz/talep dengesine ne kadar cevap verebileceği ya da bireylerin bu faaliyetler sonucunda ne kadar yetkinlik sahibi olabilecekleri sorunudur.

İkinci olarak, esneklik ve güvence kavramlarına teoride eşit ağırlık verilmiş olsa da, yukarıda da bahsedilen Komisyon metinlerinde böyle bir eşitlikten bahsetmenin mümkün olmadığ 1 görülmektedir. Komisyon metinlerinde güvence yerine esnekliğe odaklanıldığı son derece açıktır. Komisyon bildirisinde esnek güvencenin dördüncü bileşeni olan modern sosyal güvenlik sistemi son derece belirsiz kalırken, ilk bileşen olan esneklik yoluyla işgücü piyasasının modernleştirilmesi AB'nin esnek güvence modeli çerçevesinde altı çizilen konu olmuştur. Komisyon tarafından yayınlanan "2008 Temel İlkeler" dokümanında, üye ülkelere işgücü piyasasının modernleştirilmesi başlığı altında istihdam koruyucu tedbirlerini daha az sıkı hale getirmeleri öğütlenmektedir. Fakat başta işsizlik sigortası olmak üzere gelir güvencesi alanında herhangi bir iyileştirmeye dönük bir tavsiye kararı bulunmamakta, bunun ötesinde Polonya'ya, yardım sistemlerini "çalışmayı teşvik edecek biçimde" gözden geçirmesi için çağrı da bulunulmaktadır. Diğer birçok ülkeye bu alanda yapılan tavsiyelerin arasında da güvencenin artırılmasına ilişkin kararları görmek mümkün değildir ${ }^{19}$. Bu durum Komisyon'un esnek güvence konusunda gerek kabul ettiği, gerekse kendi yaptığı tanımlarla çelişmesi sonucu doğurmaktadır. Esnek güvence konsepti içerisinde güvence kavram1 ${ }^{20}$;

18 Melahat Güray, Main Challenges and Shortcomings: Unbalanced Approach of the European Commission and Feasibility of Flexicurity at National Levels - Denmark and Spain Cases-, Dublin Üniversitesi, İrlanda, 2008, s.24,25

19 Avrupa Komisyonu, "Recommendation for a Council Recommendation on The 2008 Up-Date of The Broad Guidelines For The Economic Policies", 2007, s.33.

20 Pascale Vielle, Flexicurity: Redefining The Security Of European Citizens, Belçika, 2007,s.4, www.ose.be/files/PolicypapersOSE/OSEPolicypaper1-Vielle-EN.pdf, (23.06.2008) 
1. Kişilerin profesyonel gelişimlerini devamlı k1larak işgücü piyasasındaki değişimlere uyum yetenekleri artıracak mesleki yeterliliğini sağlamalıdır (ki bu $\mathrm{AB}$ Komisyonunun güvence kavramına ilişkin olarak üzerinde durduğu en önemli konudur),

2. Eşitlik ilkesi çerçevesinde bireylere iş ve özel hayatlarını istedikleri gibi bütünleştirme hakkını garanti altına almalıdır ve

3. Hepsinden önemlisi kişilerin geçici ya da sürekli olarak işgücü piyasası dışında kalmaları halinde korunmalarını sağlamalıdır. Burada korunma sağlık, barınma, enerji, sosyal refah, eğitim, ulaşım, iletişim gibi çeşitli alanları içermektedir. Bunların sağlanması bireyleri aktif hale gelmeleri ve uyum yeteneğine sahip olmalarının yanında demografik sorunların çözümü, sosyal kaynaşma ve eşitsizliğin azaltılması için gereklidir. Aksi halde Komisyon bildirisinde ifade edilen "Modern Sosyal Güvenlik Sistemi” tam olarak anlamını karşılayamayacağı düşünülmektedir.

Oysa Komisyonun 2003 tarihli ve 842 say1lı sosyal güvenliğin modernleşmesine ilişkin yukarıda değinilen bildiride sosyal güvenlik faydalarını hak etme koşullarının ağırlaştırılmasını da içeren kimi önlemler üye ülkelere tavsiye edilmektedir.

Üçüncü olarak, esnek güvence, politika yapıcılarının kararlarını mazur göstermek için kullandıkları bir genel konsept haline dönüşebilmektedir. AB kurumları düzeyinde esnek güvence konsepti ve konseptin bileşenleri için bazı tanımlamalar yapılmışsa da, üye ülkeler düzeyinde kabul edilmiş ortak ve açık bir tanım mevcut değildir. Üye ülkeler için hazırlanan "dört patika"nın da yeni bir tanımlamadan ziyade, mevcut tanımların yeniden düzenlenmesi olarak görmek mümkündür ${ }^{21}$. $\mathrm{Bu}$ durum $\mathrm{AB}$ düzeyinde oluşturulan konseptin, her üye ülkede kasitlı ya da kasıtsız olarak farklı anlaşılmasına ve farklı kullanılmasına neden olmaktadir.

Komisyon tarafından yayınlanan belgelerde göz ardı edilen bir diğer konu ise esnek güvence ile ilgili ortaya konan hedeflere ulaşmak

21 Güray, s.26 
için ihtiyaç duyulan finansal kaynağın miktarı ve kaynağı hususudur. Bu çerçevede Komisyon tarafından yapılan tek öneri, esnek güvenceye ilişkin maliyetlerin, sağlam ve sürdürülebilir bütçe politikaları ile uyumlu olması gerekliliğidir $^{22}$. Hareketliliğin artırılması, yaşam boyu öğrenme ve sosyal güvenlik maliyeti yüksek politikalardır ve bazı üye ülkelerin hâlihazırda bu politikalar için ayırdığı kaynak düşük düzeydedir. Komisyon’un teorik tanımı doğrultusunda esneklik ile doğru orantılı biçimde güvenceyi artırabilmek için bu ülkelerin yeni kaynak bulmaları ya da mevcut kaynaklarını yeniden ayarlamaları gerekecektir. Fakat Euro alanındaki ülkeler, Maastricht Kriterleri doğrultusunda s1k1 para politikaları izlemeleri yönünde baskı altındadırlar. Bu anlamda Komisyon, özellikle Güney Avrupa ülkeleri ile yeni üye ülkelere, uzun dönemli finansal sürdürülebilirliğin desteklenmesi için emeklilik sistemlerindeki reform çalışmalarının devamlılığının sağlanmasını tavsiye etmektedir ${ }^{23}$.

Son olaraksa, Komisyon'un tanımlaması doğrultusundaki esnek güvence modellerine geçiş konusunda $A B$ üyesi ülkelerin hazır olup olmadığı hususu bir soru olarak ortaya çıkmaktadır. Örneğin Avrupa düzeyinde yaşam boyu öğrenme sisteminin istihdam güvencesinin destekleyebilecek seviyede olmadığı yönündeki kuşkular ileri sürülmektedir ${ }^{24}$.

\section{Sonuç}

Avrupa Birliği düzeyinde Birliğin sahip olduğu gücün, başta Amerika Birleşik Devletleri olmak üzere diğer gelişmekte olan ülkelere karşı korunması için daha rekabetçi ve uyum yeteneği gelişmiş politikalar geliştirmesinin en öncelikli hedef olarak ortaya konmaktadır. Özellikle işgücü piyasasındaki katılıkların yok edilmesi ve işgücü piyasasının uyum gücünün yükseltilmesi için bu alanda esnekliğin teşvik edilmesi, Birlik düzeyinde bu hedefe ulaşmak için kullanılan önemli bir araçtır. Fakat geleneklerin ve kültürel yapının etkisi nedeniyle Amerika Birleşik Devletleri'nde izlenen tarzda bir politika izleyemeyen Avrupa Birliği, özellikle Kita Avrupas1, orta yol olarak esnek güvence kavramını geliştirmiştir. $\mathrm{Bu}$ makale ile incelenen AB'de sosyal güvenliğin modernleşmesi süreci, esnek güvence uygulamaları ile eşgüdüm içerisinde

22 Avrupa Komisyonu, Towards Common, s.24.

23 Güray, s.26

24 Andranik Tangian, "Is Europe Ready for Flexicurity? Empirical Evidence, Critical Remarks and a Reform Proposal”, Intereconomics, Mart/Nisan, 2008, s.111. 
ve hatta kimi yerlerde eşanlamlı olarak kullanılmaktadır.

Avrupa Birliği'nde esnek güvencenin temel hedefi, esneklik ve güvenlik politikalarının eş zamanlı ve birbirini destekler biçimde uygulanmalarıyla, bir taraftan işgücüne katılım ve istihdam oranlarının yükseltilmesinin hedeflenirken, diğer taraftan da tek tek çalışanların ve bütün olarak işgücü piyasasının uyum yeteneği ve rekabet gücünün artırılmasıdır. $\mathrm{Bu}$ doğrultuda esneklik ve güvenlik politikalarının birlikte ve herhangi birinde ödün verilmeden uygulanacağına atıflar yapılsa da, yapılan inceleme sonucunda görülmüştür ki, esnekliğe ilişkin tavrını net biçimde ortaya koyan Avrupa otoritesi, güvenlik konusunda yeterince açık olamamaktadır. Güvenlik politikaları bakımından istihdam/istihdam edilebilirlik güvencesine büyük önem atfeden Avrupa Birliği, bir taraftan da gelir güvencesinin altını çizmektedir. İstihdam edilebilirliğin artırılması, bireylerin pasif olarak işlerini kaybetmekten korunması yerine, aktif tedbirlerle işlerini kaybetmekten korkmamaların sağlanması anlamına gelmektedir. $\mathrm{Bu}$ anlamıyla son derece modern bir bakış açısına dayanan istihdam güvencesi, ancak çok iyi kurgulanmış aktif istihdam ve hayat boyu öğrenme politikalarının uygulanması ile başarıya ulaşabilecektir. Fakat tek tek bireylerden oluşan işgücü piyasasının hızla değişen ihtiyaçlar doğrultusunda, aynı hızla yeniden eğitilmesi ve bu yapılırken tüm bireylerin faydasına uygun hareket edilmesi oldukça zor ve karmaş1k bir süreçtir. Bu çerçevede, literatürdeki çalışmalar AB Komisyonunun esnek güvencenin gerekliliği üzerine kanıtlarını yetersiz ya da dürüstlükten uzak bulmaktadır. $\mathrm{Bu}$ anlamda $\mathrm{AB}$ 'de tek paranın hayata geçirilişi sırasında yapılan eleştirilere benzer şekilde, esnek güvence uygulamalarının da sadece neo-liberal politikaları gizleyen bir örtü olduğu da ifade edilmiştir.

Gelir güvencesi konusunda ise Avrupa Birliği, esnekliği teşvik edici unsurları ön plana çıkarmaktadır. Her ne kadar işsiz kalan kişilerin ve dezavantajlı grupların korunması konusunda çeşitli önlemler önerse de, yapılan incelemeden Avrupa otoritesinin, bu alandaki hedefinin gelir güvencesinin, esneklik politikalarıyla çakışmadan ve/veya esnekliği önceleyerek uygulanmasının sağlanmasıdır. Sosyal güvenliğin modernleştirilmesi yönünde yapılan çalışmaların hedefleri de bu amacı işaret etmektedir. Ayrıca gelir politikalarının finansal kaynağının nasıl bulunacağı sorusu da AB Komisyonunca cevaplanmamaktadır. 
AB sosyal koruma ve sosyal politikaya bakışı üyelik sürecindeki Türkiye açısından da büyük önem taşımaktadır. Her ne kadar AB sistemi içerisinde sosyal koruma rejimleri, ülkelerin ulusal politika alanına bırakılmış da olsa, belirlenen asgari değerler ve ilkelere uyum sağlamak üye ülkelerin de sorumluluğundadır. Bu anlamda ortaya çıkan değişimleri yakından takip etmek ülkemizin çıkarına olacaktır. 


\section{Kaynakça}

Andranik Tangian, Is Europe Ready for Flexicurity? Empirical Evidence, Critical Remarks and a Reform Proposal, Intereconomics, Mart/Nisan, 2008

Avrupa Komisyonu, Towards Common Principles of Flexicurity: More and Better Jobs Through Flexibility and Security, 2007

Avrupa Komisyonu, What is Flexicurity, 2007

Avrupa Komisyonu, Recommendation for a Council Recommendation on the 2008 Up-Date of The Broad Guidelines For The Economic Policies, 2007

Avrupa Komisyonu, Integrated Guidelines For Growth And Jobs (20082010), 2007

Avrupa Komisyonu, Employment in Europe, 2006

European Expert Group on Flexicurity, Flexicurity Pathways, 2007

Hans Jensen, Jorn Neergaard Larsen, The Nordic Labour Markets and The Concept of Flexicurity, European Policy Centre Working Paper No. 20, 2005

Lars Calmfors, Flexicurity - An Answer or a Question, European Policy Analysis, İsveç, 2007

Maarten Keune, “Flexicurity: The New Cure for Europe's Labour Market Problems?", Social Develeoments in the European Union, Belçika, 2007

Maarten Keune, Maria Jepsen, "Not Balanced and Hardly New: the European Commission Quest for Flexicurity", ETUI- REHS, 2007

Melahat Güray, Main Challenges and Shortcomings: Unbalanced Approach of the European Commission and Feasibility of Flexicurity at National Levels - Denmark and Spain Cases-, Dublin Üniversitesi, İrlanda, 2008

Pascale Vielle, Flexicurity: Redefining The Security Of European Citizens, Belçika, 2007

Ton Wilthagen, Mapping Out Flexicurity Pathways in the European Union, Tilburg Flexicurity Research Programme, 2008

Ton Wilthagen, Frank Tros, The Concept of "Flexicurity": A New Approach to Regulating Employment and Labour Markets, Tilburg Flexicurity

Research 2004 